$\mathrm{V} \Delta \mathrm{K} 327$

ББК 66.4(4/8)

A.V. Tofan, post-graduate student of the Political Science Department, Kyrgyz-Russian Slavic University named after the First President of Russia B.N. Yeltsin

\section{THE USA'S}

PARTICIPATION

IN THE INTERNAL

POLICY

OF THE THIRD

COUNTRIES

(CASE STUDY

OF THE FORMER SOVIET REPUBLICS)

The US participation in the internal policy of independent states by the example of former Soviet republics is considered. Two approaches to the nature of "color revolutions" are analyzed: the perception of "color revolutions" as a spontaneous or a stage-managed phenomenon. The transnational corporations' participation in the US foreign policy is analyzed.

Key words and word-combinations: "color revolutions", foreign influence, USA, TNC.
A.B. Тофан, аспирант кафедри политологии Кьгргозско-Российского Слаһянского университета имени пербого Президента России Б.Н. Ельцина (email:alina_tofan@mail.ru)

\section{УЧАСТИЕ США ВО ВНУТРЕННЕЙ ПОАИТИКЕ ТРЕТЬИХ ГОСУААРСТВ (на примере постсоветского пространства)}

Аннотация. Рассматривается участие США во внутренней политике независимых государств на примере республик постсоветского пространства. Анализируются два подхода к природе «цветных революций»: понимание «цветных революций» как феномена стихийного и как феномена инсценированного. Исследуется участие транснациональных корпораций во внешней политике США.

Ключевые слова и словосочетания: «цветные революции», внешнее влияние, США, ТНК.

$\mathrm{P}$ менил всю геополитическую картину мира и сложившуюся систему межАународных отношений. На политической карте образовались пятнадцать новых независимых респубцик, которые сразу же привлекци к себе интерес со стороны Соединенных Штатов Америки. США начали рассматривать новые государства через призму построения однополярного мира, используя новые государства в качестве объектов своей геополитической экспансии. Искусственно разрушая прочные исторические связи, не допуская реинтеграции постсоветского про-

34 Bulletin of the Volga Region Institute of Administration • 2017. Vol. 17. № 3 
странства посредством реализации «цветных революций», этнизации и хаотизации, США пытаются установить такой мировой порядок, который будет строиться на Аиктуемых ими принџипах, закрепцяя за собой роль мирового арбитра и единственной сверхдержкавы.

Политические проџессы в современных постсоветских государствах во многом происходят не без участия США. «Первостепенный интерес Америки состоит в том, чтобы помочь обеспечить такую ситуацию, при которой ни одна держава не контролировала бы данное геополитическое пространство, а мировое сообщество имело бы к нему беспрепятственный финансово-экономический Аоступ» [1, с. 178]. Аанный постулат 3. Бжезинского как немьзя кучше характеризует современное положение Аел, при котором США, не пренебрегая даже самыми непопулярными или противоречащими межАународному праву методами, вмешиваются во внутреннюю политику Аругих государств с џелью реализовать свои собственные геополитические стратегии.

Отметим, что современные особенности внешнего вмешательства США во внутренние дела третьих государств заключаются в том, что США реализуют не столько свои собственные государственные стратегии, сколько интересы и задачи транснациональных корпораций, которые, формируя из своих дохоАов большую часть американского бюджета, используя администрацию США, склонны реализовывать свои корпоративные стратегии.

Современные ТНК опреАеляют модели экономической и политической картины мира, находятся в одном шаге от формирования надгосударственного мирового правительства. Значимую роль ТНК в мировом процессе подчеркивает и тот факт, что при ООН создана Комиссия ООН по ТНК, в рамках которой обсуждается деятельность разАичных корпораций на самом высоком уровне. ТНК активно участвуют во многих политических процессах, широко преАставлены в экономической, финансовой, научно-технической сферах. Более того, крупные ТНК обцадают своими собственными спецслужбами, органами разведки и контрразвеАки, а оружием, которое ежегодно производит одна мишь General Dynamics Corporation, можно вооружить не одну армию [2] .

ТНК заинтересованы в своем присутствии в экономически неразвитых странах, при этом эти страны домжны отвечать следующим требованиям ТНК: наличием дешевой рабочей силы, низкими ставками налогов, наличием источников сырья, низким уровнем государственного регулирования, возможностью размещения на территории государства экологически вредного производства и Аругими. Еще в ХХ в. ТНК активно вмешивались во внутренние дела Аругих государств, политика которых по той или иной причине шла вразрез с цемями корпораций. Так, ряд американских ТНК однажАы стали организаторами беспорядков в Панаме, Коста-Рике и Гондурасе, создав дия этой цели фонд в 5 млн домларов США, финансировали покушения на Ф. Кастро, и т.А. [2]. Сегодня интересы ТНК обслужкивает администрация США, по большому счету, зависимая от них финансово: Аоходы от деятельности ТНК явцяются одним из главных источников пополнения бюджета США.

К примеру, механизм, способ вмешательства США во внутренние процессы третьих государств принято называть технологией «мягкой силы» - soft 
power, с помощью которой США захватывают власть в определенном госуАарстве и передают ее в руки удобным мидерам. Технологию soft power, peализуемую в таком виде, вполне можно назвать технологией осуществления государственных переворотов. Более того, известный пубцицист С. Хелемендик настаивает на том, что администрация США использует технологию soft power не столько Аля отьема и передачи власти, сколько Аля передела собственности (так, после государственного переворота в Словакии все стратегические объекты перешли в руки США, а точнее, в руки американских ТНК) и Аля реализации стратегических целей Запада (к примеру, если администрация США поставица себе цель разместить военную базу в непосреАственной близости к России и Китаю, то в это время в центрацьноазиатских государствах начинается кампания за демократизацию и свободу; американские ТНК заинтересовались контролем наА транзитом нефти с Каспия, и «волна демократизации» прокатилась по государствам Кавказа) [3] .

Помимо транснациональных корпораций существуют и дополнительные игроки, не явцяющиеся привычными геополитическими еАиниџами, которые представлены наркокартелями, террористическими организациями, национамистическими группировками и преступными сообществами. Аанные субъекты, в отличие от государств, не связаны межАународными обязательствами, границами, они мобильны и мегко создают горизонтальные и вертикальные связи Аруг с Аругом. При этом, если ТНК реацизуют свои собственные корпоративные интересы, цель которых в первую очередь увеличение прибыли и расширение производства, то наркобизнес, преступные и террористические организаџии не обладают кичными интересами и вполне готовы реализовывать цели третьих миџ и выступать в качестве инструмента дестабилизаџии ситуации [4].

Итак, США, пытаясь сохранить «однополярность», беззастенчиво вмешиваются во внутреннюю политику суверенных государств, Аиктуя им свои правияа игры, приводя к вцасти своих ставленников и посредством этого реацизуя свои геополитические интересы. Так, в сентябре 1996 г. конгресс США принял резоцюџию № 120, в которой четко прописац ацгоритм действий украинской политической элиты, в том числе президента, парламента и правительства, Аля демократизаџии Украины и неАопущения реинтеграции постсоветских государств. Следующая резолющия по Украине была принята в 2004 г., в которой указывалось, что, если в ходе проведения выборов президента Украины будут выявлены нарушения, правительство США введет санкции. Кроме того, администрация США профинансироваца установцение в постсоветских государствах проамериканских режимов. Например, к началу 2004 г., сразу после грузинской «револющии роз» 2003 г., в ходе которой к власти пришец американский ставленник М. Саакашвили, американская помощь Грузии превысила 1,3 мирА домларов США. В реализаџии «тюльпановой револющии» в Кыргызстане активно принимала участие организация «Коалиџия за демократию и гражданское общество», которая получала финансирование со стороны Национального Аемократического института США. При этом отметим, что миАер указанной НПО Э. Байсалов в 2004 г. во время «оранжевой революции» 
1,5 месяџа провел на Украине, набираясь опыта, и впоследствии, в 2005 г., выступил одним из организаторов «революџии тюльпанов» в Кыргызстане, а в 2006 г. был удостоен награды Американской ассоџиации юристов «За выдающиеся усилия в продвижении верховенства закона».

Бесспорно, справедливо мнение исследователей, что технологии «цветных революций», экспорта демократии, демократических ценностей и институтов - исключительно англосаксонское изобретение. Следовательно, в мюбом государстве, где реализуются технологии «цветных револющий», присутствует североамериканский смеА [5, с. 6]. Как мюбой феномен, «цветные рево-

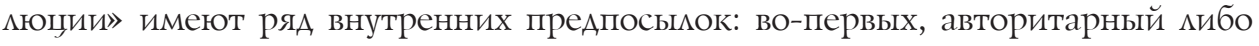
псевдодемократический политический режим, при котором ограничивается Аоступ различных сощиальных слоев и групп к доминирующей мибо правящей группе; во-вторых, наличие большого числа недовольных граждан, которые впоследствии становятся той группой, из которой рекрутируются участники акций неповиновения; в-третьих, наличие большого числа гражАан, недовольных текущими политическими, экономическими, соџиальными условиями, и которые, тем самым, активно мибо пассивно поддерживают идею «цветной революции»; в-четвертых, слабый контроль мибо вообще его отсутствие со стороны властных структур за СМИ, НПО, интернет-ресурсами; в-пятых, нацичие в государстве сильной оппозиции во главе с авторитетными киАерами, которые разделяют идеи «цветной революџии»; в-шестых, отсутствие политического мидера, который смог бы мобилизовать резервы обществ против внешнего вмешательства [6] .

ГАавная цель «цветной револющии» - слом старого политического режима и создание новой политической системы, подконтрольной внешнему игроку в циџе США. «Цветные революџии» влекут за собой смену политической элиты, что, по сути, призвано носить конструктивный характер: новая элита, приАя во власть, способна преодолеть застой, снизить уровень политической напряженности, однако, фактически это влечет за собой усугубление политического кризиса, кризиса соџиальной системы, снижает уровень доверия народа к власти и в целом приводит к еще большему застою, то есть декларируемый Аемократический транзит не реализуется.

В данном контексте актуально высказывание Президента РФ В.В. Путина о том, что «демократию нельзя экспортировать из одной страны в Аругую. Также как нельзя экспортировать револющию, также как нельзя экспортировать идеологию» [7]. Кроме того, А. Ае Токвиль в работе «Старый порядок и ревомюџия», изданной еще в 1856 г., сформулировал ряд законов революџионного развития, один из которых весьма удачно выражается старой французской поговоркой: «Самый быстрый путь к свободе ведет к наихудшей форме рабства». Суть здесь в том, что привнесение демократических ценностей в госуАарства, где исторически отсутствуют традиџии демократии, реформирование политической системы, которое идет вразрез с традиционным жизненным укмадом, формировавшимся веками, в конечном итоге приведет к дестабилизации государственной власти и помяризаџии соџиальных классов. Эти события вполне могут выйти из-поА контроля тех игроков, которые начали это рефор- 
мирование. «В результате вместо демократических институтов и ценностей в этих странах может установиться еще худшая форма тиранической власти, чем быма Ао начала реформаторской деятельности» [6] .

Следовательно, США, реализуя свои стратегические интересы посредством подАержки оппозиџионной Аеятельности, революџии и миквиАаџии политических режимов, мишь прикрываются интересами гуманитарного характера: распространением демократических ценностей, подАержкой прав человека, борьбой с терроризмом. Как правило, декларируемые США цели на деле оказываются предлогом дия политического, финансового, военного, информационного, идеологического вмешательства во внутреннюю политику интере-

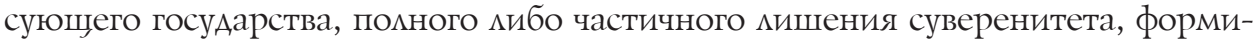
рования системы государственной вмасти, подконтрольной США [8, с. 16] .

Существует несколько мнений о природе «цветных революций». Сторонники первого подхода рассматривают цветные революџии как явление стихийное, причина которого кроется в соџиальных противоречиях, системном кризисе, нищете, демографической ситуации, которые находят свое выражение в массовых выступлениях, бунтах, протестах демократически настроенных неправительственных организаций, которых поддерживает широкий круг

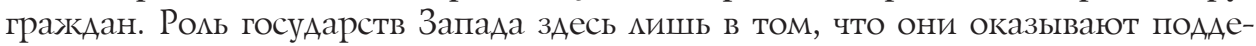
ржку НПО Аля реализации их целей. Этот процесс обоснован в первую очередь внутренними противоречиями в обществе и дискредитаџией действующей вмасти. Государства Запада играют здесь отнюдь не ключевую роль [6] .

Сторонники второго подхода настаивают на том, что «цветные революции» - феномен инсценированный, многократно повторяющийся по одной и той же схеме во многих государствах; объективные же причины сощиальных протестов размичны [5, с. 8]. Исследователи этой группы рассматривают «цветные революџии» как проџесс, организованный и контролируемый западными спецслужбами, конечная цель которого - не Аопустить интеграции государств постсоветского пространства с Россией. Приверженец Аанного подхода С. Кара-Мурза полагает, что «цветные революџии» носят геополитический характер, реализовываясь в рамках установления моноџентричной мировой системы во главе с США. Такие революџии исследователь называет неоколониальными, подчеркивая, что в результате «цветных революций» изменяется геополитический вектор государства, равно как и меняются основы мегитимности государственной вцасти, так как источник мегитимности вы-

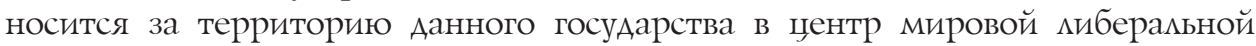
системы - в США [9, с. 259].

С. Кара-Мурза настаивает на том, что причины «цветных революций» в постсоветских государствах следует рассматривать не в контексте конкретных целей администрации США, а в формировании нового мирового порядка. Современные постсоветские республики не способны стать частью этого нового миропорядка, поскольку они все еще обладают собственной мегитимностью, пусть и весьма ограниченной, которая досталась им в наследство от Советского Союза. Новый мировой порядок предполагает, что постсоветские государства Аолжны стать его частью в качестве государств, обцадающих 
внешней мегитимностью, полученной от США. Именно США должны быть признаны сувереном наА постсоветским пространством, иметь возможность разрешать кризисы, подчеркивая свое положение «гаранта мирового поряАка». Соответственно, одной из целей «цветных революџий» является установление такой власти, источник мегитимности которой будет находиться в США [10, с. 117].

Таким образом, особенность внешнего воздействия в современных условиях заключаются в следующем: политическими акторами являются не государства, а ТНК и финансовые элиты под видом (внешним прикрытием) и от имени государств. Отсюда и спещифика такого воздействия - внешние акторы заинтересованы не в реформировании или изменении государственных политических институтов, а скорее, в их уничтожении; не в смене верхушки государственной власти и в ее геополитической ориентаџии, а в изменении мегитимности всей государственности и источника ее местонахождения: с территории данного государства в ядро мировой системы капитализма. При этом декларируется џель - распространение западной соџиальной политики (Аипломатическая, экономическая помощь, коммуникации и связь). ОАнако западную модель невозможно успешно переносить на государства незападного типа. Итак, прикрываясь этой целью, США проводят политику хаотизации межАународных отношений Амя того, чтобы впоследствии иметь возможность цегитимно этим хаосом управмять в роли гаранта стабимьности мирового порядка, реализуя не только свои государственные стратегии, но и стратегии транснациональных корпораций.

\section{Библиографический список}

1. Бжезинский 3. Великая шахматная доска. Господство Америки и его геостратегические императивы. М., 1998.

2. Самофалов В. Глобальный вызов транснациональных корпораций. URL: http:/gazeta. zn.ua/ECONOMICS/globalnyy_vyzov_transnatsionalnyh_korporatsiy.html

3. Хелемендик C. Soft power - мягкая сила «made in USA». URL: http://expert.ru/2009/02/6/ Soft Power/

4. Некрасов Р. Революции «нового поколения» в Средней Азии. Предчувствие «Первой национал-террористической». URL: http://www.odnako.org/blogs/revolyucii-novogo-pokoleniyav-sredney-azii-predchuvstvie-pervoy-nacional-terroristicheskoy/

5. Манойло А.В. Цветные революции и технологии демонтажа политических режимов // Международные отношения. 2015. № 1. С. 1-19.

6. Пономарева Е. Секреты «цветных революций»: Современные технологии смены политических режимов. URL: http://www.mgarsky-monastery.org/kolokol/4450

7. Путин: Демократию нельзя экспортировать. URL: https://www.vedomosti.ru/library/articles/2005/09/19/putin-demokratiyu-nelzya-jexportirovat

8. Красинский В.В. Выборы как механизм захвата политической власти и реализации иностранной внешней политики // Военно-юридический журнал. 2006. № 3. С. 15-21.

9. Кара-Мурза С.Г. Экспорт революции. Ющенко, Саакашвили... М., 2005.

10. Кара-Мурза С., Александров А., Мурашкин М., Телегин С. На пороге «оранжевой» революции. М., 2005. 